\title{
Legal Assessment on the Potential of Post-Expansion Patterns International Competition
}

\author{
Halimatul Maryani ${ }^{1 *}$, Rahmadany ${ }^{2}$, M. Taufik Siregar ${ }^{3}$, Muhammad Ridwan Lubis $^{1}$, \\ and Dani Sintara ${ }^{1}$
}

\author{
${ }^{1}$ Universitas Muslim Nusantara Al Washliyah Medan, Indonesia \\ ${ }^{2}$ Universitas Amir Hamzah, Medan, Indonesia \\ ${ }^{3}$ Universitas Medan Area, Indonesia \\ ${ }^{*}$ Corresponding author email: halimatul.maryani@umnaw.ac.id
}

\begin{abstract}
The AFTA-China regional free trade is a new challenge. Indonesia is now entering the era of AFTA-China international competition. Whereas in free trade AFTA-China has joined through ACFTA (Asean China Free Trade Agreement), in the Framework Agreement on comprehensive Economic Co-operation Between the Association of South East Asian and The People's Republic of China (Asean-China). The Indonesian government and China will cooperate in the industrial sector, with the hope that the cooperation between the two countries, for Indonesia, can encourage Chinese investment in Indonesia, especially cooperation in industrial technology including trade. Labuhan Batu is a district located in the province of North Sumatra (Indonesia), where the regional potential is such as agriculture and plantations, facilities and infrastructure are quite superior and have great potential in responding to AFTA-China international competition, especially post-expansion with the hope of existing potential. the area is ready to compete in the international market.
\end{abstract}

Keywords: Regional Potential, AFTA-China, Concept of Expansion

\section{INTRODUCTION}

Globalization is a word that is often discussed among economists and legal experts as well as the public, both nationally and internationally, because globalization is expected to bring important changes to the world [1]-[4]. The talk of globalization is a coherence that is always associated with free trade as well as the free market mechanism, the World Trade Organization (WTO), where the entry of goods and services from one element to another without being subject to tariffs or also known as the absence of artificial barriers (barriers determined by the government) in the trade cycle with an open system (transparency), so that the business world of each member country can compete fairly and wisely [5]-[7]. AFTA is an organization that aims to increase the volume of trade between member countries in the ASEAN region.

The emergence of the issue regarding the AFTA-China regional free trade is a new challenge that inevitably, like it or not, the Indonesian State is now entering the era of
AFTA-China international competition. Whereas in the free trade AFTA-China has joined through ACFTA (Asean China Free Trade Agreement), in the Framework Agreement on comprehensive Economic Co-operation Between the Association of South East Asian and The People's Republic of China (Asean-China). The Indonesian government and China will cooperate in the industrial sector, with the hope that the cooperation between the two countries, for Indonesia, can encourage Chinese investment in Indonesia, especially industrial technology cooperation, including trade.

This means that challenges as well as opportunities must be achieved with the concept that all the potentials in Indonesia can compete in the international market, of course it is inseparable from the superior potential of an area whose small scope is through "Districts" or "Small Cities", because the Regency is a sub-part of the Indonesian Territory, one example, for example in this study, the writer focuses specifically on the area of 
Labuhan Batu Regency as the object of legal study to be studied, because according to the researcher's analysis this is very important and very useful for the Labuhan Batu Government, especially the Labuhan Batu community. Through analysis, in this case, the Labuhan Batu Regency has a significant role and potential in responding to international competition including AFTA-China regional trade, this can be seen from the plantation sector, including agriculture, fisheries and other crop products. Along with this, the economic condition of Labuhan Batu Regency will be analyzed by comparing the level of progress or economic growth rate of Labuhan batu before and after expansion. Because the idea of implementing this expansion basically has developed from an early age by looking at the implementation of the expansion of other districts. Thus, it is hoped that the people of Labuhan Batu will be more prosperous, especially after Labuhan Batu was expanded. This means that in accordance with the superior potential of the existing Labuhan Batu Region, it is sufficient to be relied on in responding to the AFTAChina international competition and is expected to reduce the amount of poverty in Indonesia, especially in the Labuhan Batu Regency area.

\section{LITERATURE REVIEW}

\subsection{Definition of Regional Potential}

The word "potential" is adapted from English, namely "potency" which means "power, ability, strength" or "potential" which means ability, ability and strength. Meanwhile, "area" is an area, territory and legal community unit which has certain regional boundaries. Thus, regional potential is the quality and quality as well as regional excellence that can be relied upon and is the availability of resources that can be utilized and can contribute to regional revenues and community welfare which can be assessed from several aspects such as financial institutions, economic facilities, educational facilities, facilities. health, transportation and communication facilities, tourism facilities, employment and so on [8]-[11].

\subsection{The Concept of Expansion}

The legal basis for the concept of expansion is in article 6 paragraph 1 of Law Number 22 of 1999 concerning Regional Government, which is also further elaborated in Government Regulation Number 129 of 2000, that a region can be divided into more than one region, which is then changed/replaced became Law Number 32 of 2004 concerning Regional Government. In this case, expansion is to provide benefits to the community by improving services and increasing welfare as well as accelerating the pace of economic growth and equitable development [12] [13].
One example through the implementation of this research is that the research location analyzed located in the Labuhan Batu Regency area with the capital city of Rantau Prapat, because Labuhan batu Regency is one of the largest districts in North Sumatra province and has been expanded in 2008 to become three districts namely Labuhan Batu Induk, North Labuhan Batu and South Labuhan Batu.

\subsection{International Competition Overview}

\subsubsection{Overview of AFTA}

ASEAN Free Trade Area abbreviated as AFTA is a form of trade cooperation between ASEAN formulated in The ASEAN Preferential Trading Arrangements/PTA and signed in 1977, then refined in The Protocol on Improvegents On Extention of Tariff Preferences Under the ASEAN Preferential Trading Arrangements/PTA. In various parts of the world, regional economic cooperation has emerged and developed. For the Southeast Asian region, the regional economic cooperation is called AFTA which was initiated and created by ASEAN [14]-[18].

The contents of the CEPT are the rules that have been mutually agreed upon by ASEAN countries in implementing AFTA. Based on the results of the ASEAN6 Trade Ministers meeting in Singapore on January 28, 1992, it was agreed that to reduce trade tariffs/duties between ASEAN to $0-15 \%$. At the 4th Summit it was decided that AFTA would be achieved within fifteen years, starting from January 1, 1993-1 January 2008 and only concerned manufactured products, then accelerated to 2003, and finally accelerated again to 2002 . Manufactured products This is included in capital goods and processed agricultural products, as well as products that are outside the category of unprocessed agricultural products which are also covered by the CEPT program.

The requirements for a product that can be traded through the CEPT program if the product meets three criteria, namely as follows.

a. These products must be registered in the Inclusion List in both exporting and importing countries and have the same tariff range, namely above $20 \%$ or below $20 \%$,

b. The product must be an ASEAN product, that is, it must meet ASEAN local content at least $40 \%$.

Products that have a tariff rate of $0-5 \%$ automatically meet the requirements of the CEPT program and will automatically enjoy the conveniences that the program provides. The purpose of establishing AFTA is to reduce all obstacles to the flow of trade and capital transactions in the ASEAN region, as well as to increase the growth rate and create a competitive advantage in the ASEAN region which refers to the provisions of the World Trade Organization (WTO). In addition, the objectives of AFTA that must be achieved are as follows:

a. to increase competitive advantage as a production base for the world market, and

b. trade liberalization, reduce tariff and non-tariff barriers between countries. 


\subsubsection{Legal Basis of the AFTA}

The legal basis for the AFTA-China agreement is the Framework Agreement on Comprehensive Economic Cooperation Between the Association of Southeast Asian Nations and the People's Republic of China, which was signed by the President of the Republic of Indonesia (Megawati) on November 4, 2002 in Phnom Penh, Cambodia, and has been ratified. by the President of the Republic of Indonesia through Presidential Decree of the Republic of Indonesia Number 48 Year 2004 concerning Ratification of the Framework Agreement on Comprehensive Economic Cooperation Between the Association of Southeast Asian Nations and the People's Republic of China.

\subsubsection{Free Trade Theory}

International trade is trade carried out by residents of a country with residents of other countries on the basis of mutual agreement, for example by glancing at the theory put forward by Adam Smith, which gave birth to the theory of justice, that the purpose of justice is to protect from losses "the end of justice is to secure from injure" which originated from the perspective of classical capitalism on international free trade based on the principle of laissez faire in his very famous work An Inquiry to the Nature and Causes of the Wealth Natio. Initially, capitalism was considered attractive enough where Adam Smith's version was believed to be able to provide welfare to society. In the Wealth of Nation Smith also describes how the price system will work and how a free and competitive economy will function without government interference.

In principle, this free trade system was also developed by John Meynard Keynes that this free trade system is a capitalist economic system controlled through state intervention. This means that Keynes stated that the need for government intervention and direct funding from the government to overcome the decline in private investment and purchasing power in order to stimulate economic recovery and bring out the concept of a welfare state (welfare state) and bring change that state interference in society greatly changes the work that can be done. by traditional law, where the large role of the state is recognized not only to ensure internal and external security, but is further responsible for a large number of injustices. The state must take a role in eliminating this injustice from the existing system through a number of economic and social interventions.

Furthermore, this is also in line with what Jhon Rawls put forward in his theory of justice, that justice is as honesty and equality (justice as fairness), which provides the greatest benefit for the most disadvantaged and opens up fair opportunities. Justice as a concept based on the principles of equality and inequality (equality and inequality) where social values, freedom and opportunity, income and prosperity based on self respect must be distributed among others.

Rawls's concept of international justice is portrayed in the context of international law and can be applied in terms of debates through procurement negotiations to avoid elements of manipulation, domination, pressure on inferior groups, hereinafter called the reciprocity criterion which also creates internal tensions in the liberal theory itself, namely the existence of tension between the theory of justice. utilitarian and liberal trade. First, that international trade must be constructed for the protection of the moral equality of all individuals who are subject to the rules. Second, justice in a liberal view requires international trade laws that apply and benefit disadvantaged countries. Third, that liberal justice promotes international law that does not sacrifice human rights and effective protection of human rights to achieve welfare (welfare gains), justice is an ideal of all interests of international trade law which is nothing but "justice".

\section{RESULTS}

\subsection{Overview of Labuhan Batu}

Geographically, Labuhan Batu Regency is located at 1026'-2011 'North Latitude, 91001-97007 East Longitude with an altitude of 0-2,151 m above sea level with an area of $9,233.18 \mathrm{Km} 2$ (pre-expansion) approximately $12.87 \%$ of the area of North Sumatra Province.

Before 1945, Labuhan Batu was an Afdeling Onder from Afdeling Asahan-Labuhan Batu based in Tanjung Balai. During the reign of the Dutch East Indies in the AsahanLabuhan Batu Onder Afdeling area, Labuhan Batu was led by fou) Sultanates, namely:

1. The Sultanate of Kualuh, based in Tanjung Balai;

2. The Sultanate of Bilah, based in Negeri Lama;

3. The Sultanate of Kota Pinang, based in Kota Pinang;

4. The Sultanate of Panai, based in Labuhan Bilik.

Administratively, initially the Labuhan Batu Regency government was led by a resident assistant (regent) while Onder (Afdeling) was led by a Counteleur (wedana). The first Labuhan Batu Counteleur (1862-1920) was in Labuhan Batu Village. Then in (1920-1924) it was moved to Labuhan Bilik, and in 1924 it was moved again to Marbau (1924-1928). Four years later he was transferred to Aek Kota Batu (1928-1932). In 1932 it was moved to Rantau Prapat and continued until the Proclamation of Independence of the Republic of Indonesia to this day. In 1965 the financial structure was abolished in accordance with Law No. 18 of 1965 . The subsequent development of the Regional Government of Labuhan Batu Regency, then adjusted again to Law no. 5 of 1974. The government structure in Labuhan Batu Regency developed with the establishment of three district assistant regents, as presented in Table 1 
Table 1 Post-expansion development of Labuhan Batu was formed in three regencies

\begin{tabular}{lll}
\hline \multicolumn{1}{c}{ Region I } & \multicolumn{1}{c}{ Region II } & \multicolumn{1}{c}{ Region III } \\
\hline Kecamatan Kualuh Hulu, Aek Natas, & Kecamatan Kota Pinang, Torgamba, & Kecamatan Panai Tengah, Panai Hillir, \\
Na IX-X, and Marbau, domiciled in & Silang Kitang, Bilah Hulu, Bilah Barat, & Panai Hulu, Kualuh Hilir, Pangkatan, \\
Aek Kanopan & $\begin{array}{l}\text { Kampung Rakyat, Sungai Kanan, } \\
\text { domiciled in Kota Pinang }\end{array}$ & domiciled in lab bilik-Rantau Prapat. \\
\hline
\end{tabular}

Table 2 The names of the Regent of Labuhan Batu (October 17, 1945 to present)

\begin{tabular}{clc}
\hline No. & The names of the Regent of Labuhan Batu & Term of Office (Period) \\
\hline 1. & Abdul Rahman (head of government) & October 1945-June 1946 \\
2. & Gause Gautama & $1946-1947$ \\
3. & Syahbuddin Siregar (Pj) & $1947-1948$ \\
4. & Djamaluddin Tambunan & $1948-1951$ \\
5. & Abdul Wahid E. R. & $1951-1954$ \\
6. & Ibnu Saadan & $1954-1956$ \\
7. & T. Badja Purba & $1956-1958$ \\
8. & Fachruddin Nasution & $1958-1959$ \\
9. & Yahya Yakub & $1959-1961$ \\
10. & H. Idris Hasibuan & $1961-1966$ \\
11. & H. Iwan Maksum & $1966-1974$ \\
12. & H. Asrol Adam & $1974-1979$ \\
13. & H. Djalaluddin Pane & $1979-1984$ \\
14. & Abdul Manan & $1984-1989$ \\
15. & H. Ali Hanafiah & $1989-1994$ \\
16. & Drs. H. B. Ispensyah Rambe & $1994-1999$ \\
17. & Drs. H. R. Hadisiswono Al Haj (Pj) & $1999-2000$ \\
18. & H. T. Milwan & $2000-2005$ \\
19. & Syaparuddin, SH (Pj) & 2005 \\
20. & H. T. Milwan & $2005-$ pre-expansion \\
21. & dr. H. Tigor Panusunan Siregar, SpPD & post-expansion \\
22 & Tigor Panusunan Siregar & 2010 \\
23 & Amran Uteh & 2015 \\
24 & Pangonal Harahap & Febuary 17,2016 \\
25 & Andi Suhaimi Dalimunthe & July 25, 2018 \\
\hline
\end{tabular}

Data source: quoted in http://earning-news.blogspot.com/2010/04/sejarah-labuhan-batu/html, accessed on Friday, July 5, 2013, developed.

It was then followed that in 1992 there was the formation of the Administrative City of Rantau Prapat, which was based on Government Regulation No. 1 of 1992. However, in its development the formation of the Administrative City was later abolished. This is because there are new provisions in Law Number 22 of 1999. So, in the provisions of PP Number 43 of 1999, Labuhan Batu Regency becomes 22 districts.

The names of Labuhan Batu Regents since the independence of the Republic of Indonesia in its history from October 17, 1945 to the present can be seen in Table 2

\section{2. The Idea of Expansion}

The emergence of the idea of expanding Labuhan Batu Regency started from the awareness of the potential and regional development of Labuhan Batu community leaders, both those in the region and those who were overseas. The historical expansion that has been carried out originated from the idea of an initiative by a number of figures from the Labuhan Batu Association of Families (IKLAB) in Medan and its surroundings who at that time mandated the Labuhan Batu Scholars Association (ISLAH) to conduct a one-day seminar on "Empowering the Potential of Labuhan Batu" as an implementation UU no. 22 of 1999 on October 26, 2002 at the Garuda Plaza Hotel Medan, with the aim of expansion according to Law no. 32 of 2004 are: Increasing services to the community, accelerating the growth of democratic life, accelerating the implementation of regional economic development, accelerating the processing of regional potentials, increasing security and order and increasing harmonious relations between the center and the regions, in this case Labuhan Batu district compared to other districts. Labuan Batu is the largest area in North Sumatra with 22 subdistricts, 242 villages/wards, and 910,502 people. 


\subsection{Potential Post-expansion of Labuhan Batu Area}

Talking about the potential of Labuhan Batu, the potential that has become the mainstay of the Labuhan Batu Regency area to date is quite a lot, for example the area and number of populations, regional culture, social politics, availability of facilities and infrastructure, security and order, and most importantly the agricultural and plantation sectors.

If viewed from the historical history of Labuhan Batu Regency, the administrative area of Labuhan Batu Regency before/pre-expansion had twenty two districts, namely, Sungai Kanan District, Torgamba District, Kota Pinang District, Silang Kitang District ;, Kampung Rakyat
District, District Bilah Hulu, Pangkat District, Marbau District, Bilah Hilir District, Panai Hulu District, Central Panai District, West Bilah District, Panai Hilir District, Rantau Selatan District, Rantau Utara District, NA IX-X District, Aek Natas District, Aek Kuo District, Kualuh Hilir District, Kualuh Selatan District, Kualuh Hulu District, Kualuh Ledong District.

Furthermore, after the division of Labuhan Batu Regency has now become nine districts with an area of 2,561.38 $\mathrm{Km} 2$ or $27.7 \%$ of the previous area, namely, Bilah Hulu District, Pangkat District, Bilah Hilir District, Panai Hulu District, Central Panai District, Panai Hilir District, Bilah Barat District, Rantau Selatan District, Rantau Utara District.

Table 3 The Population of Labuhan Batu Regency (distribution and population density of Labuhan Batu)

\begin{tabular}{lrrrrrrr}
\hline \multirow{2}{*}{ Districts } & Large Territory & \multicolumn{3}{c}{ Total population } & \multicolumn{3}{c}{ Population density } \\
\cline { 2 - 7 } & \multicolumn{1}{c}{$\left(\mathrm{km}^{2}\right)$} & 1999 & 2003 & 2007 & 1999 & 2003 & 2007 \\
\hline Bilah hulu & 293,23 & 45,527 & 50,157 & 55,257 & 154 & 171 & 189 \\
Pangkatan & 355,47 & 26,811 & 29,347 & 31,908 & 75 & 83 & 90 \\
Billah Barat & 202,98 & 25,012 & 28,952 & 32,534 & 128 & 143 & 160 \\
Bilah Hilir & 430,83 & 38,262 & 48,302 & 53,165 & 89 & 112 & 123 \\
Panai Hulu & 276,31 & 27,571 & 29,214 & 33,127 & 99 & 106 & 120 \\
Panai Tengah & 483,74 & 25,720 & 27,480 & 30,226 & 53 & 57 & 62 \\
Panai Hilir & 342,03 & 32,160 & 33,628 & 36,408 & 94 & 98 & 106 \\
Rantau Selatan & 64,32 & 33,825 & 44,590 & 50,642 & 525 & 693 & 787 \\
Rantau Utara & 112,47 & 58,287 & 70,004 & 77,313 & 518 & 624 & 687 \\
Kabupaten Labuhan Batu & $2,561.38$ & 313,175 & 361,674 & 361,674 & 400,580 & 232 & 156 \\
\hline
\end{tabular}

Data source: Labuhan Batu Regency in the figures and results of the consultant's analysis in 2009 and adjusted to the number of sub-districts after the division

In addition to the area and population of Labuhan Batu Regency, in this case, the area includes Natural Resources (SDA) and can be seen and analyzed, of course, from land use and production, which focuses on the agricultural and plantation sectors. Plantation products are raw materials for processing industries that process raw materials into raw materials. This means that the plantation for the Labuhan Batu Regency area is one of the potential supporters in the economic development of Labuhan Batu. Apart from that, it also includes the wealth of its natural resources, such as food crop farming, fisheries, forest products and others.

Table 4 and 5 present the post-expansion of Labuhan Batu economic growth rate in response to AFTA-China.

Table 4 PDRB Labuan Batu Regency based on current price and constant prices from 2005 to 2009

\begin{tabular}{cccc}
\hline No. & Year & $\begin{array}{c}\text { Prices Apply } \\
\text { (Million IDR) }\end{array}$ & $\begin{array}{c}\text { Constant Price 2000 } \\
\text { (Million IDR) }\end{array}$ \\
\hline 1. & 2005 & $4.037 .869,88$ & $2.486 .163,31$ \\
2. & 2006 & $4.653 .909,45$ & $2.618 .785,72$ \\
3. & 2007 & $5.257 .085,40$ & $2.792 .160,35$ \\
4. & $\left.2008^{\mathrm{r}}\right)$ & $6.077 .301,55$ & $2.957 .401,27$ \\
5. & $\left.2009^{*}\right)$ & $6.658 .794,89$ & $3.101 .701,08$ \\
\hline
\end{tabular}

Table 5 PDRB per capita Labuhan Batu Regency based on current prices and constant prices from 2005 to 2009

\begin{tabular}{cccc}
\hline No. & Year & $\begin{array}{c}\text { Prices apply } \\
\text { (Million IDR) }\end{array}$ & $\begin{array}{c}\text { Growth rate } \\
(\%)\end{array}$ \\
\hline 1. & 2005 & $10,659.75$ & 18.95 \\
2. & 2006 & $11,845.66$ & 11.13 \\
3. & 2007 & $13,114.09$ & 10.71 \\
4. & $\left.2008^{\mathrm{r}}\right)$ & $14,855.40$ & 13.28 \\
5. & $\left.2009^{*}\right)$ & $15,946.00$ & 7.34 \\
\hline
\end{tabular}

Note: *) interim figures; r) improvement figures Source: BPS Labuhan Batu

Table 6 Economic Growth Labuhan Batu Regency 2005 to 2009

\begin{tabular}{cccc}
\hline No. & Year & $\begin{array}{c}2000 \text { Constant Price } \\
\text { (Million IDR) }\end{array}$ & $\begin{array}{c}\text { Growth rate } \\
(\%)\end{array}$ \\
\hline 1. & 2005 & $6,563.33$ & 3.58 \\
2. & 2006 & $6,665.63$ & 1.56 \\
3. & 2007 & $6,965.20$ & 4.49 \\
4 & $\left.2008^{\mathrm{r}}\right)$ & 7.229 .10 & 3.79 \\
5. & $\left.2009^{*}\right)$ & $7,427.73$ & 2.75 \\
\hline
\end{tabular}

Note: *) interim figures; r) improvement figures

Source: BPS Labuhan Batu 
Table 7 Distribution of Percentage of Labuhan batu Regency based on the prevailing price according to the business field 2005 to 2009 (\%)

\begin{tabular}{llrrrrr}
\hline No. & \multicolumn{1}{c}{ Business field } & \multicolumn{1}{c}{2005} & \multicolumn{1}{c}{2006} & \multicolumn{1}{c}{2007} & \multicolumn{1}{c}{$\left.2008^{\mathrm{r}}\right)$} & \multicolumn{1}{c}{$\left.2009^{*}\right)$} \\
\hline$(1)$ & \multicolumn{1}{c}{$(2)$} & \multicolumn{1}{c}{$(4)$} & \multicolumn{1}{c}{$(5)$} & \multicolumn{1}{c}{$(6)$} & \multicolumn{1}{c}{$(7)$} \\
\hline 1. & PRIMARY & 25.40 & 20.12 & 20.65 & 21.12 & 21.14 \\
& a. Agriculture & 24.04 & 18.47 & 18.93 & 19.43 & 19.43 \\
& b. Mining and excavation & 1.36 & 1.65 & 1.72 & 1.69 & 1.71 \\
\hline 2. & SECONDARY & 47.82 & 47.90 & 49.16 & 49.06 & 47.54 \\
& a. Management Industry & 45.09 & 44.42 & 46.09 & 46.04 & 44.50 \\
& b. Electricity, Gas, Clean Water & 0.40 & 0.46 & 0.49 & 0.45 & 0.45 \\
& c. Building & 2.33 & 3.02 & 2.58 & 2.57 & 2.59 \\
\hline 3. & TERTIARY & 26.78 & 31.97 & 30.20 & 29.82 & 31.31 \\
& a. Trade, Hotel, Restaurant & 15.89 & 17.19 & 16.51 & 16.60 & 17.15 \\
& b. Transport and Communication & 3.46 & 4.41 & 4.45 & 4.26 & 4.44 \\
& c. Finance, Rental and Company services & 1.21 & 1.51 & 1.35 & 1.35 & 1.39 \\
& d. Services & 6.22 & 8.86 & 7.89 & 7.61 & 8.33 \\
\hline & Labuhan Batu & 100.00 & 99.99 & 100.01 & 100.00 & 99.99 \\
\hline
\end{tabular}

Table 8 Labuhan Batu Post-expansion

\begin{tabular}{clll}
\hline No. & Post-Expansion District & Capital city & \multicolumn{1}{c}{ Regent's name } \\
\hline 1. & Labuhan Batu Selatan & Kota Pinang & H. Wildan Aswan Tanjung \\
2. & Labuhan Batu Induk & Rantau Prapat & dr. H. Tigor Panusunan Siregar, SpPD \\
3. & Labuhan Batu Utara & Aek Kanopan & H. Kharuddin Sitorus, B.E. \\
\hline
\end{tabular}

Labuhan Batu Regency (Rantau Prapat) includes: Bilah Hulu District, Pangkatan District, Marbau District, Bilah Hilir District, Panai Hulu District, Panai Tengah District, Bilah Barat District, Rantau Selatan District, and Rantau Utara District. Labuhan Batu Utara Regency, (Aek Kanopan) includes: NA IX-X District, Aek Natas District, Aek Kuo District, Kualuh Hilir District, Kualuh Selatan District, Kualuh Hulu District, and Kualuh Ledong District. Labuhan Batu Selatan Regency, (Pinang City) includes: Sungai Kanan District, Torgamba District, Kota Pinang District, Silang Kitang District, and Kampung Rakyat District.

\section{CONCLUSION}

Based on descriptions that have been analyzed and presented in chapters and sub-chapters in the discussion, including abstracts, background, problem formulation, objectives and benefits, literature review, research methods, future stage plans, analysis and discussion. So, to summarize what has been described. For more details, it can be concluded as follows that the results of the study are seen from the aspect of regional potential regarding the potential of the Labuhan Batu Regency area which is very potential and sufficient to be relied on in responding to the international competition of AFTA-China and of course, hope that it will not be less competitive in international markets.

\section{REFERENCES}

[1] U. R. Mir, S. M. Hassan, M. M. Qadri, Understanding Globalization and its Future: An Analysis, Pakistan Journal of Social Sciences, 34 (2) (2014), 607-624.

[2] M Surugiu, C. Surugiu, International Trade, Globalization and Economic Interdependence between European Countries: Implications for Businesses and Marketing Framework. Procedia Economics and Finance, 32 (2015), 131-138.

[3] M. L. Fernandez, Challenges of Economic Globalization. Rev. Relac. Int. Estrateg. Segur.,12 (1) (2017), 23-50.

[4] Z. M. Awdel, N. M. Odel, W. F. Saadi, The Rise of The Globalization and Its Effect on The Autonomy of State and Political Economy. Journal of Critical Reviews, 7 (6) (2020), 998-1000.

[5] C. Chikozho, E. Mapedza, Free-Market Economics and Developmental Statism as Political Paradigms: Implications for Water Governance Theory and Practice in Developing Countries. In: Karar E. (eds) Freshwater Governance for the 21st Century. Global Issues in Water Policy, 6 (2017). Springer, Cham. 
[6] H. Baetjer Jr., Economics and Free Markets. Washington: Cato Institute, 2017.

[7] J. Weeks, Free Markets and the Decline of Democracy. Review of Radical Political Economics, 50 (4) (2018), 637-648.

[8] B. Storrank, Unlocking regional potentials. Nordic Council of Ministers, 2017.

[9] K. E. Wardhana, Regional-Potential-Based Plantation Vocation Education Analysis in East Kalimantan Province. Jurnal Pendidikan Vokasi, 8 (1) (2018), 88-96.

[10] B. Kharisma, F. Hadiyanto, Analysis of Potential Sectors and Policy Priorities of Regional Economic Development in Maluku Province. Etikonomi, 18 (1) (2019), 29-46.

[11] E. P. Yudha, R. A. Dina, Pengembangan Potensi Wilayah Kawasan Perbatasan Negara Indonesia (Studi Kasus: Ranai-Natuna). Tata Loka, 22 (3) (2020), 366378.

[12] C. Asmussen, B. Nielsen, T. Osegowitsch, A. Sammartino, The Dynamics of Regional and Global Expansion. Multinational Business Review, 23 (4) (2015), 306-327.

[13] Syarifuddin, R. A. Damayanti, Good governance and fiscal capacity in regional expansion: A holistic analysis of qualitative perspective. Journal of Economics, Business, and Accountancy Ventura, 18 (1) (2015), 15-28.

[14] Y. Effendi, Asean Free Trade Agreement Implementation for Indonesian Trading Performance: A Gravity Model Approach. Buletin Ilmiah Litbang Perdagangan, 8 (1) (2014), 73-92.

[15] A. F. Aritenang, The Impact of the AFTA Tariff Reduction on Districs Economic Growth in Indonesia. Journal of Regional and City Planning, 26 (1) (2015), 18-27.

[16] A. Balik, Pengaruh Perdagangan Bebas AFTA dan ACFTA bagi Industri dalam Negeri. Jurnal Sasi, 21 (2) (2015), 33-41.

[17] Rusmini, Asean Free Trade Area (AFTA): Peran Manajemen Pendidikan Islam terhadap Pengembangan Character Building di Kota Jambi. Journal of Management in Education, 1 (1) (2016), 70-79.

[18] H. Akhmadi, Assessment the Impact of Asean Free Trade Area (AFTA) on Exports of Indonesian
Agricultural Commodity. Journal of Agribusiness and Rural Development Research, 3 (1) (2017), 9-14. 